\title{
Andy Kissane
}

\section{'The gun went off': teaching the writing of violence}

\begin{abstract}
This essay canvasses a range of literary approaches to the writing of violence in fiction. It analyses practical modes of writing violence in contemporary novels: violence from the perspective of a witness or victim; the creation of psychic distance; focalisation through a 'less-violent' character; and violence as allegory. It also discusses the implications of violent student writing for the classroom in the context of authorial responsibility, cultural studies and the potential scope and function of the writing workshop.
\end{abstract}

'I'd love to start by cutting her back straight down the spine. After that I could cut her head clean off, feeling every little vein and artery burst in half. I hear once the head is removed people can still function for up to a minute.'

- Student manuscript (used with permission)

Given the prevalence of violence in the media, from schlock splatter movies to the nightly news, it is not surprising that students produce violent scenes in their creative work. Yet in my experience students rarely write violence well. Their violent scenes are graphic and detailed, sometimes misogynistic, but in most cases the violence simply seems to exist for its own sake, it rarely contributes to an interesting thesis about life and human behaviour, and it rarely assists the development of the work in aesthetic terms. The American short story writer Lorrie Moore seems to have had a similar experience. In response to the controversy around the publication of American Psycho, she wrote:

As a writing teacher I have seen over the last decade more than one short story that featured hacked-up women - almost always written by 20 -year-old boys. Lately, however I have been seeing even more of these kinds of stories. It's like David Lynch the boys say now. Or else: It's like David Lynch; it's deliberately false, stylized, absurd. Get it? (Moore 1990)

But when confronted with violent texts in a workshop situation, creative writing teachers can do more than simply ask students not to write violence because some readers or fellow students might be offended by the work. A more effective approach is to say, 'Okay, if you want to write violence let's look at how you can do it successfully, both from an ethical and moral position and from an aesthetic and craft-based position.' For as any writer who has tried knows, writing violence, like writing sex, is not easy. In an interview published in Rolling Stone, Bret Easton Ellis described the difficulty of writing the torture and murder scenes in American Psycho: 
They were incredibly upsetting to write - the hardest scenes I've ever had to write for obvious reasons. Yet at the same time I knew they had to be there. ... These scenes were probably more upsetting to write because I had to keep writing $I$ all the time. $I$ do this. $I$ did that. That does a number on you psychologically that I can't quite describe. I don't think I could tell you how I felt after writing these scenes. I cried a few times. (in Love 1991: 39-40; emphasis in original)

So in this essay I propose to do two things: to investigate the range of techniques and approaches utilized by contemporary novelists when writing violence from both a craft and an ethical standpoint and to consider how these exemplary 'violent' texts can be used to broaden and deepen a workshop discussion of student writing. The four contemporary novelists whose work I will discuss in detail are JM Coetzee, Cormac McCarthy, Kate Grenville and Bret Easton Ellis.

\section{Coetzee's Waiting for the Barbarians: the witness and the victim}

JM Coetzee argued that South African writers were faced with a difficult dilemma - either to avoid the obscenity of state-condoned torture or to produce representations of these obscenities. If writers decide to write about torture, then their challenge is 'how not to play the game by the rules of the state, how to establish one's own authority, how to imagine torture and death on one's own terms' (Coetzee 1986: 364). Coetzee's critique of novelistic violence is a fundamentally political one. What he objects to are not representations of violence per se, but representations that assist the state in terrorizing the populace and paralyzing resistance. The torture chamber is difficult terrain for a novelist to traverse, but Coetzee travels there himself in his 1980 novel, Waiting for the Barbarians.

The narrator of the novel is a magistrate, a choice that ensures that he is officially implicated in the campaign by the Empire to subdue the barbarians. By using a first person witness narrator, Coetzee forgoes any access to the consciousness of the torturer or the tortured, unless of course the magistrate takes on those roles. I suspect that by positioning his narrator as an observer, Coetzee aimed to stay out of the dark chamber, to avoid the erotic fascination he finds in the representations of Sipho Sepamla's A Ride on the Whirlwind or the 'questionable dark lyricism' he finds in the novels of Mongane Serote and Alex La Guma (Coetzee 1986: 364). By choosing to employ a first person witness narrator, Coetzee avoids the overly predetermined positions of 'torturer' and 'tortured'. As Coetzee suggests, there are many dangers associated with the representations of a torturer, such as caricaturing the torturer as satanically evil, or simplifying him as a faceless functionary, or characterising him as 'a tragically divided man doing a job he does not believe in' (Coetzee 1986: 364).

Coetzee initially stays out of the dark chamber in Waiting for the Barbarians, positioning the magistrate as sympathetic to a tortured barbarian woman, though still implicated by his colonial power. But in the second half of the novel the descriptions of violence become more explicit and detailed. Watching the public humiliation of a group of naked barbarian prisoners, the magistrate describes how the word ENEMY is written in charcoal on the prisoners' backs and how they are beaten by soldiers and by other townspeople, until their backs are washed clean by their own blood. This scene recalls Michel Foucault's argument in Discipline and Punish that the people had a dual role in ceremonies of public execution - being both spectators and participators in the 
performance (Foucault 1977: 57). Coetzee dramatizes the voyeurism and curiosity of the public and also fosters an awareness in the reader of his/her own voyeuristic tendencies.

Inevitably, the magistrate is dressed in a woman's smock and taken out of the jail to be humiliated and tortured (Coetzee 2000: 128). What strikes me the most when reading this is the dramatic tension and suspense created by the threat of violence. It's the threat of violence that is potent and viscerally affecting as the magistrate is perched precariously on the top rung of a ladder with a rope around his neck. As readers we are unsure of the magistrate's fate and focus on whether he will be hanged or spared. Suddenly he is let down, but only momentarily so Mandel can show him 'another form of flying' (Coetzee 2000: 132; emphasis in original). Coetzee then describes an act of violent torture that is unusual and strange, a common technique in novelistic depictions of violence. The arresting and the strange, either in event or character, are hallmarks of much engaging fiction, and often utilized in literary representations of violence. The rope is now tied to the magistrate's wrists and he is hauled up into the air:

But I am as weak as a baby, my arms come up behind my back, and as my feet leave the ground I feel a terrible tearing in my shoulders as though whole sheets of muscle are giving way. From my throat comes the first mournful dry bellow, like the pouring of gravel. (Coetzee 2000: 132)

By now I suspect that many readers have imaginatively identified with the magistrate and are reacting as if the violence is happening to their bodies. It's as if we have been strung up on the mulberry tree ourselves and are better able to comprehend the pain, fear and helplessness of the victim. This is the power of the scene - it is both visceral and disturbing. In Waiting for the Barbarians the absurdity of violence and torture is emphasized and reinforced. Coetzee presents a kind of hell, a hell created by the dehumanizing force of an imperial power, in order to argue against the creation of such hells in the future.

This approach to writing violence, as a witness then as a victim, is the simplest and least problematic for a writer. It draws on the genres of testimony and confession, accounts typically associated with the victims of violence. Coetzee's approach is useful for students because it demonstrates the impact that fiction can have on a reader through the development of empathy and understanding. The violent scenes are also inextricably linked to an analysis of imperialism, where the absurdity of the violence against the barbarians is reinforced. And Coetzee manages to play the game on his own terms and create representations of violence that are neither suffused with erotic fascination nor directed towards assisting the state in maintaining terror. The value of Waiting for the Barbarians is that it demonstrates how much can be done in fiction. This novel is a great antidote to students who write violence for its own sake, without situating the violence within a broader analysis of the world.

For students who want to write violence from the perspective of the perpetrator, there is the danger that this textual violence will alienate some readers. I will consider three novels with violent perpetrators in order to illuminate some of the issues and approaches students can consider in developing their own work.

\section{McCarthy's Blood Meridian: the use of psychic distance}

Blood Meridian is probably the most violent book I have read, yet as a reading experience it was both exhilarating and unforgettable. Robert Jarrett has 
suggested that 'some readers justifiably might charge that the style of McCarthy's novel creates a pornography - or is it a sadography - of violence' (Jarrett 1997: 89). McCarthy's style and some of the other choices he makes as a writer are markedly different from Coetzee's and provide another possible approach to writing violence.

The novel begins by following a character only referred to as 'the kid'. The kid's mother has died in childbirth, his father is a drunken schoolmaster. By the age of fourteen, when he runs away from Tennessee, 'he can neither read nor write and in him broods a mindless violence' (McCarthy 1990: 3). This mindless violence is illustrated again and again in the novel. The kid joins Captain White's filibusters, who are campaigning in the late 1840 s to make Sonora, and as much of Mexico as possible, into American territory. They haven't gone far when they are attacked by Comanches. This is how McCarthy describes the height of the Comanche raid, in one long, skillfully written sentence:

Now driving in a wild frieze of headlong horses with eyes walled and teeth cropped and naked riders with clusters of arrows clenched in their jaws and their shields winking in the dust and up the far side of the ruined ranks in a piping of boneflutes and dropping off the sides of their mounts with one heel hung in the withers strap and their short bows flexing beneath the outstretched necks of the ponies until they had circled the company and cut their ranks in two and then rising up again like funhouse figures, some with nightmare faces painted on their breasts, riding down the unhorsed Saxons and spearing and clubbing them and leaping from their mounts with knives and running about on the ground with a peculiar bandylegged trot like creatures driven to alien forms of locomotion and stripping the clothes from the dead and seizing them up by the hair and passing their blades about the skulls of the living and the dead alike and snatching aloft the bloody wigs and hacking and chopping at the naked bodies, ripping off limbs, heads, gutting the strange white torsos and holding up great handfuls of viscera, genitals, some of the savages so slathered up with gore they might have rolled in it like dogs and some who fell upon the dying and sodomized them with loud cries to their fellows. (McCarthy 1990: 53-54)

This passage, like the rest of Blood Meridian, is written in third person objective narration. The narrator gives us only what is seen and what is said, as if the scene is recorded by a camera and tape recorder. It is very filmic writing, so it comes as no surprise when Robert Jarrett compares McCarthy's use of the present participle in the Comanche charge with the long slow-motion massacre scene that concludes the Peckinpah film The Wild Bunch (Jarrett 1997: 89). The long sentence McCarthy uses for the Comanche charge seems to increase the pace of the narration, carrying the reader along as event follows horrible event. Yet there is also a desire to linger - to consider how shields can wink in the dust, to picture the nightmare faces - so the pace paradoxically seems to be both furious and slow at the same time. An increase in pace is a common technique in descriptions of violence, and it is certainly used by McCarthy to mimic the suddenness and chaos of the conflict.

Another technique that McCarthy uses here is the avoidance of individual focalisation. The kid's horse is shot from underneath him. For a few sentences we follow what he sees, but we soon lose him and are swept up in the choreography of the charge. If there is a point of view, it is a Comanche one, as 
in 'strange white torsos', but mostly the events are recorded from afar - in precise and minute detail, but still from afar. This use of psychic distance is crucial in understanding how McCarthy writes such a shockingly violent book without alienating his readers in the process. It is this consistent distance that controls the way readers approach the text.

McCarthy never comments on the violence in any ethical or moral manner; the violence simply exists in human society, as it does in nature. McCarthy's objective narration serves to treat the natural world with the same emphasis as the human world, so that the novel, as Dana Philips has argued, functions as a critique of literature's anthropocentrism (Philips 1996: 443-48). McCarthy depicts violence, sudden death and all other calamities as natural, as part of a philosophical orientation in which humans are no more significant than the physical world through which they traverse. This philosophy is articulated in a much-quoted passage when Glanton's men ride through the desert:

They rode on. The horses trudged sullenly the alien ground and the round earth rolled beneath them silently milling the greater void wherein they were contained. In the neuter austerity of that terrain all phenomena were bequeathed a strange equality and no one thing nor spider nor stone nor blade of grass could put forth claim to precedence. The very clarity of these articles belied their familiarity, for the eye predicates the whole on some feature or part and here was nothing more luminous than another and nothing more enshadowed and in the optical democracy of such landscapes all preference is made whimsical and a man and a rock become endowed with unguessed kinships. (McCarthy 1990: 247)

'Optical democracy' is a useful term for McCarthy's compositional strategy in which the landscape and nature are as central to the novel as any of the characters. The wilderness does not exert a civilizing influence, it does not promote better men, it just exists. Sometimes there is a collision between natural forces and men, as in the memorable scene where a bat drinks Sproule's blood and he responds with 'a howl of such outrage as to stitch a caesura in the pulsebeat of the world' (McCarthy 1990: 66). Both the natural world and the human world are violent and once that violence has begun, the consequences are inevitably destructive and brutal.

In considering Blood Meridian's unceasing violence I once thought that McCarthy's technique was to organize the narrative from the perspective of a 'less-violent' character, the kid. The kid is violent, but he is certainly not as violent as Glanton or Judge Holden. He is prepared to assist wounded comrades like David Brown and unwilling to shoot Dick Shelby, who has his hip shattered and cannot continue. Despite his propensity for 'mindless violence', he appears less mindless and cold-blooded than the other scalp hunters. Judge Holden's assessment of the kid is telling: 'There's a flawed place in the fabric of your heart. Do you think I could not know? You alone were mutinous. You alone reserved in your soul some corner of clemency for the heathen' (McCarthy 1990: 299).

But in this case at least, the theory of a less violent character says as much about my approach to reading Blood Meridian as it does about McCarthy's narrative techniques. I wanted to find some explanation and rationale for the violence at the level of a character's consciousness. I wanted to understand what it felt like to kill and scalp, to be part of a violent rampage. This desire for interiority is a common expectation that readers bring to novels, yet it is an expectation that McCarthy ignores. There is no sense of character development 
or growth in Blood Meridian, no representation of individual consciousness. The only possible exception to this are the speeches of Judge Holden, but as Dana Phillips has argued, these speeches are more literary performances, compounds of Nietzschean and Spenglerian rhetoric, than a development of a convincing interiority (Phillips 1996: 442).

McCarthy's use of third person objective narration creates a psychic distance that controls the way a reader assimilates this very violent novel. The complete absence of interiority and character development keep ethical and moral questions at an arm's length. It is tempting to read the book as an indictment of the American myth of manifest destiny, and although Blood Meridian does utilise historical events, it does not seem intent on illustrating an ideological thesis. Violence in literature is often seen as more tenable and less gratuitous if it has a purpose, if it serves a critique such as a denunciation of imperialist conquest. If such a critique is suggested by Blood Meridian, it seems more accidental than by design. McCarthy does not adjudicate or editorialise, he does not judge any individual or any event. As Denis Donoghue suggests: 'The pervasive style of the book holds every consideration at a distance from the events, with the result that a critical or ethical impulse finds itself thwarted at every point' (Donoghue 1998: 267). By avoiding traditional novelistic characterization and maintaining psychic distance through his use of optical democracy, McCarthy writes a novel that is both incessantly violent and incessantly readable. And Blood Meridian's value, for a student who wants to write violence, is in the questions it raises. Is third person objective narration, because of its avoidance of what a character thinks and feels, a useful approach for writing violence? Do violent acts need to be accompanied by ethical and moral qualifications and judgments provided by a narrator, an implied author or another character? Or does violence just exist, as it seems to in the world, often eluding both understanding and rational explanation? And to what extent are the successes of McCarthy's depictions of violence dependent on his prose style? McCarthy's style is not one that would be easy to imitate, but it is a fine example of how much can be achieved at the level of the sentence, setting a suitably high standard to aspire for.

McCarthy's novel and the most pedestrian piece of schlocky student violence have one thing in common: they both have the potential to open up the discussion of what writers can achieve through their writing. This is why student drafts of violence (or sex or any other taboo subject) should never be dismissed, but always enthusiastically embraced. Such a discussion can lead to the most fruitful airing of questions, not just about novelistic craft, but about the role and function of writing in society and the need for a writer to critically reflect on what she is trying to do and why.

\section{Grenville's The Secret River: the 'less-violent' character}

Kate Grenville's award-winning novel of Australian conquest, The Secret River, is an interesting contrast to Blood Meridian. Grenville does use the device of the 'less-violent' character in her dramatization of frontier violence in colonial Australia. The most violent character in attitude and deed is the onedimensional Smasher, who carries a whip and dangles a pair of Aboriginal ears from his belt. His deeds and attitudes are judged and condemned by the main character, William Thornhill. As the conflict between the white settlers and the blacks deepens, and Thornhill has to choose between the land that he has taken up on the Hawkesbury and his wife who wants to leave, it is Smasher who suggests the solution: 'Sterminate them, Smasher said. No one going to come 
straight out and say it, but ain't it the only way?' (Grenville 2006a: 298; emphasis in original).

Thornhill reluctantly agrees to use his boat to ferry the settlers downriver to massacre the blacks. Grenville's focus is on how a good man 'could go and do what only the worst of men would do' (Grenville 2006a: 300). On the trip down the river, Thornhill has time to contemplate his actions, to wonder 'how his life had funnelled down to this corner, in which he had so little choice?' (Grenville 2006a: 300). During the massacre itself, Thornhill is hapless and clumsy, much more of an observer than an active participant: 'After that first shot things had moved too fast around Thornhill. He pointed his gun at blacks as they ran but the muzzle was always too late' (Grenville 2006a: 305).

A reluctant killer, an honest man with a conscience, is easier for a reader to empathize with than a cold-blooded murderer. Thornhill is drawn as the good man, Smasher as the eager killer. And what Grenville does with Thornhill in this scene is very interesting. When it comes to descriptions of Thornhill acting violently, his agency is diminished by the use of the passive voice. The emphasis shifts from Thornhill as a responsible adult, capable of choice, to the gun, as if the gun were somehow independent and autonomous. Grenville writes: 'The gun was still up at Thornhill's shoulder, his finger was against the trigger, but he could not move, a man in a dream. He was aware of issuing orders to pull back on the trigger, but nothing happened' (Grenville 2006a: 307). Thornhill's state of panic and reduced awareness is intercut by the spearing of Smasher, but when Grenville returns the narrative to Thornhill and he actually shoots the Aborigine, Whisker Harry, Grenville returns to the passive voice: 'The gun went off with a puff of blue smoke and a pop that sounded puny in all this air' (Grenville 2006a: 307).

Guns are fired, they don't just go off. As readers we know that Thornhill has killed Whisker Harry, but it is easier for readers to accept a violent hero if the focus is on the gun and not on the character who kills. The rest of the massacre scene confirms Thornhill as the 'less-violent' character. After pulling the trigger he closes his eyes, he watches Whisker Harry examine his wound and he puts the gun down. There's a catalogue of dead blacks lying among the ruins of their humpies. Dan deals with the wail of a baby by striking the baby with a club. Smasher dies. Grenville finishes the chapter by shifting from past to present tense and from individual focalization to an objective third person viewpoint: 'And a great shocked silence hanging over everything' (Grenville 2006a: 309).

It's a powerful scene to read and one that effectively deals with our cultural silence at the theft of Aboriginal land. Grenville makes the theft clear in numerous ways in The Secret River, but I find it curious that the violence of the central character is so muted, that when Thornhill acts he is so absent from his own actions, in such a dream, incapable of pulling the trigger. The gun just goes off. The character of Thornhill is based on Grenville's great-great-great grandfather, Solomon Wiseman, and perhaps this explains her reluctance to make his violence active rather than passive (Grenville 2006b: 3, 188).

Grenville notes her reluctance to write the massacre scene, which she based on accounts of the historical Waterloo Creek massacre:

These scenes of violence were the most difficult I'd ever written. Even now I don't want to look at them too closely. They had to be written because the story needed to include this aspect of the frontier, but I had to steel myself to write them. (Grenville 2006b: 162) 
Given Grenville's emphasis on choice, both in the novel and in her account of writing it, it's curious that Thornhill's choice to kill is so absent from the novel's climax. It is certainly easier for a reader to accept if the central character is less violent than the other characters, if his actions can be rationalized, explained, understood. Thornhill's role in the massacre stays with him, and Grenville convincingly suggests the hollowness and emptiness of his subsequent state that 'did not feel like triumph' (Grenville 2006a: 334). Yet as a reader I'd have preferred it if Thornhill had pulled the trigger as a subject, in the active voice. For me it's the difference between saying the land was settled and we stole the land. The Secret River is a fine novel, brutally honest about our colonial beginnings, yet not quite honest enough.

For a student attempting to write violence, Grenville demonstrates the difficulties of writing a convincing violent protagonist. Smasher, the most violent character, is an overly simplistic caricature, and one of the few weaknesses of the novel. Thornhill is strangely absent from his own violent actions, though not from either the build-up to the massacre or its aftermath. The violence is never gratuitous but always directed towards dramatizing the violence of our colonial history and our dispossession of Indigenous people. Again, Grenville is an interesting model that can be used to broaden student understanding of the difficulties encountered when writing violence and the range of solutions that can be considered.

\section{Ellis's American Psycho: reading violence, allegorical violence}

Bret Easton Ellis's American Psycho is unmistakably brutal, written from the point of view of the psychopath, Patrick Bateman, using first person narration. It is an appropriate text to discuss with students because it raises the issue of how to write sexual violence, and provides a case study of adverse reactions to textual violence. American Psycho created a controversy before it was even published, after the rejection of the contracted manuscript by Simon $\&$ Schuster, its subsequent sale to Random House and the printing of particularly violent extracts in Time and Spy. Tammy Bruce, the president of the Los Angeles chapter of the National Organization for Women (NOW) campaigned for a boycott of the book and of all Random House and Vintage titles. Bruce read violent passages aloud on a local hotline and then denounced the book. In a January 1991 resolution, NOW stated that 'the publication of American Psycho is socially irresponsible and legitimizes inhuman and savage violence masquerading as sexuality' (Freccero 1997: 50). Bruce went on to accuse the book of being a 'how-to manual on the torture and dismemberment of women' (Young 1992: 86).

I suspect that this condemnation of American Psycho was based on violent extracts that were read without any sense of the context or significance of the violence within the work as a whole. The violence is read in the most naïve manner conceivable, as being 'real', and as capable of inciting others to violence. It is without doubt a gross misreading of Ellis's novel that illustrates more about simplistic assumptions about the effect of reading violence than about the work itself.

The initial critical response to American Psycho is also suggestive of how many readers approach violence. One emblematic example is Norman Mailer's review, 'The Children of the Pied Piper' published in Vanity Fair in March 1991. Mailer did not object to Ellis's project or his critique of society, but he brought an expectation to his reading that Ellis had never attempted to fulfill. Mailer wrote: 'Since we are going to have a monstrous book with a monstrous 
thesis, the author must rise to the occasion by having a murderer with enough inner life for us to comprehend him.' Later he suggested: 'We cannot go out on such a trip unless we believe we will end up knowing more about extreme acts of violence, know a little more, that is, of the real inner life of the murderer' (Mailer 1991: 182).

What I would suggest readers want, perhaps many readers, is to understand violence. In particular, they want to understand the motivation, justification and consciousness of a person capable of excessive violence, understand what makes him/her tick, understand the 'inner life'. Given the realist novel's reliance on and celebration of character throughout much of its history, and the novel's capacity to represent consciousness, this expectation seems reasonable. As the literary critic Carla Freccero notes, 'What critics reproach Ellis for is that he precisely does not provide a psychologized narrative of origins, a comforting etiology for his killer's illness; we do not hear that he was a sexually abused child or that he had a domineering mother' (Freccero 1997: 51).

But an attentive reading of American Psycho suggests in numerous ways that it was never Ellis's intention to write a realistic psychological portrait of a serial killer. The novel is an unremitting satire of consumer capitalism and the cultural obsession with designer clothes, household gadgets and things. This is the overwhelming thesis that this novel of ideas makes, rendered in the interior monologue of Patrick Bateman towards the end: 'Surface, surface, surface was all that anyone found meaning in ... this was civilization as I saw it, colossal and jagged' (Ellis 1991: 375). When you enter this world of commodity-speak you are entering a hell from which there is no exit, as the allusion to Dante at the beginning, and the novel's ending make clear. It is a critique that seems appropriate to the excesses of the Reagan years in the US and other capitalist economies, where the obsession with things, ends up turning people into things. That Bateman treats people like commodities, like things, is one of Ellis's contentions, and writing violence without any psychological justification inevitably turns people into things. As Simone Weil eloquently suggests about Homer:

To define force - it is that $\mathrm{x}$ that turns anybody who is subjected to it into a thing. Exercised to the limit, it turns man into a thing in the most liberal sense: it makes a corpse out of him.

Somebody was here, and the next minute there is nobody here at all; this is the spectacle the Iliad never wearies of showing us. (Weil 1986: 183; emphasis in original)

I did not find the violence in American Psycho disturbing or confronting because I was always aware of the fictional nature of the violence. The violence is not realistically convincing because Patrick Bateman is not convincing as a literary character; he is constructed from the discourses of magazine advertising and pornography, and his responses are saturated with a range of upper class and racist prejudices. Young links the frustration felt by critics to 'a vague sense of Patrick's insubstantiality as a "character"' (Young 1992: 118). She suggests that 'the person who tells the story, who fantasizes about impossible murders does not exist in any traditional fictional sense ... Patrick is device' (Young 1992: 118).

Furthermore, a number of critics highlight the unreliability of Patrick as a narrator and the possibility that the murders are imagined by Patrick and do not take place (Mandel 2006: 16; Murphet 2002: 46-49; Young 1992: 118). Patrick's absence as a character is made explicit by his own metafictional commentary on his presence: 
... there is an idea of a Patrick Bateman, some kind of abstraction, but there is no real me, only an entity, something illusory, and though I can hide my cold gaze and you can shake my hand and feel flesh gripping yours and maybe you can even sense our lifestyles are probably comparable: I simply am not there. It is hard for me to make sense on any given level. Myself is fabricated, an aberration. (Ellis 1991: 376-77)

Ellis creates deliberate doubt in American Psycho about whether the violent murders actually happen or are imagined. But the violence is aesthetically necessary to complete Ellis' critique of the vapidness and pointlessness of consumer capitalism and its disregard for others. As Julian Murphet argues, the novel is set at the time when 'the new ruling class of Reagan's America was inflicting all kinds of violence on workers, homeless people, ethnic minorities and women, in effect much worse than the lurid and rococo violence of Bateman's discourse' (Murphet 2002: 54). The violence in American Psycho has an allegorical power that more than justifies its existence in the novel. It is not violence that serves the state by terrorizing the populace, rather it is violence that is crucial to Ellis's satire of a ruling elite, and a lifestyle that turns people into things.

For students writing violence, American Psycho raises the contentious area of sexual violence and the circumstances in which textual representations can be justified. It is particularly useful as a response to violent schlock, for it demonstrates how Ellis uses violence to add a metaphorical completeness to his scathing critique of materialistic values. It also underlines the difficulty of writing violence from the perspective of the protagonist, for although Ellis' novel is an aesthetic success, like McCarthy and Grenville, he does not give us a psychologically convincing killer.

To my knowledge the best examples of the portrayal of the inner life of a murderer are Dostoevsky's portrait of Raskolnikov in Crime and Punishment and Patrick McCabe's socially deprived, lonely and disturbed Francie in The Butcher Boy. By concentrating on the representation of consciousness, both authors lead us to a position where the violent actions of their main characters are never condoned, but can certainly be understood. With Raskolnikov we get an insight into the deceptions and fevered logic of his mind and a sense that although he meticulously plans the murder, he is never sure of actually committing it, up until the very last moment. The sources of Francie's violence seem to be deeply rooted in social circumstances - his mentally disturbed mother, alcoholic father and the heartbreaking isolation that occurs when his only friend is sent to a boarding school. As Mailer wishes for in American Psycho, here are murderers we can comprehend. In both books, the violence is dramatic, graphic and disturbing and the murderers have a character-logical depth that Patrick Bateman never approaches. Here are two exemplary models of violent protagonists who are psychologically convincing.

\section{Teaching the writing of violence: implications for classroom practice}

The question of how to approach this subject in the classroom raises a number of significant issues about pedagogical practice. Foremost among them is the way a topic like writing violence reminds me that, ideally, the workshopping of student texts should not be limited to questions of craft alone. Because of the theoretical approach adopted, because of time constraints or simply because what I am proposing is harder to do, there is tendency in workshopping to concentrate on a micro-analysis of a text at the level of sentence, image and 
idea. A narratological perspective that considers issues such as characterization, voice, utilization of scene and summary, structure and so on is also prone to be dominated by questions of craft. And a diagnostic approach where suggestions offered might include: 'Could the story start at a different place?' 'Can you hold this scene longer?' 'Can you prepare for this ending better?' and 'Can you dramatize this so the reader can imagine it more fully?' is also likely to focus on the craft of storytelling.

All of these approaches are valuable for students and they are of vital and ongoing interest to writers. As a writer, I care about scenes that have dramatic power, that move me; I care about writing that offers a new way of seeing the world and is written in language that is fresh, vital and memorable. One of my own teachers, John Scott, used to say that 'there should not be one bad sentence in a novel' and I agree with him and hold to that maxim. I care about writing at the level of the sentence and the paragraph, and ultimately at the level of the right or best word, and I want my students to do the same.

But reflecting on my own teaching practice over a number of years, I have gradually come to see that this is not always enough: that the writing workshop, if it is to fulfill its potential, should not merely focus on techniques and questions of craft. Perhaps one of the advantages of teaching the writing of violence is that issues of a broader nature are inevitably foregrounded.

A number of academics have discussed the problems associated with a purely craft-based approach to workshop poetics. Anne Surma writing in TEXT emphasized 'the danger of slipping into a concentration of skills and competencies and the mechanics of writing, in isolation from an investigation into the social and public contexts of its circulation, function, meaning and value for both writers and readers' (Surma 2000). Paul Dawson also argued for a sociological workshop poetics that considers not only the choices a writer makes in terms of craft, but also considers how these choices are political and ideological as well. This sociological poetics encourages student writers 'to see themselves as inescapable participants in a social dialogue through the practice of writing' (Dawson 2003).

One of the most lucid contributions to this field is Chris Green's 'Materializing the Sublime Reader: Cultural Studies, Reader Response and Community Service in the Creative Writing Workshop.' Examining American workshop practices Green notes that, 'Creative Writing classes focus almost exclusively on textual close reading, following more closely than anywhere in English departments the tenets of New Criticism' (Green 2001: 158). Green concentrates on the teaching of poetry, but his argument applies to all genres. Rather than consider a poem in a vacuum, he wants to shift the focus from teaching students to write 'good' poems to writing useful poems. 'Only after the potential use of a poem is established within specific cultural institutions of production, distribution and consumption can poets then judge how to train themselves to write "good" poems that can act with efficacy within particular cultural situations' (Green 2001: 159).

Green's analysis draws perceptively on the practice of cultural studies which considers the way texts are framed and exist within a culture, why texts are composed by the writer and how they might be read or used by a reader. This approach leads to a different set of questions being asked in the workshop. The critic Jane Tompkins puts it this way: 'I ask, "what kind of work is this novel trying to do?" My assumption in each instance has been that the text is engaged in solving a problem or a set of problems specific to the time in which it was written' (Tompkins 1985: 38; quoted in Green 2001: 165). We can certainly 
teach our students to write well or write better, but we can also occasionally shift the focus to a consideration of other aspects of writing. As Green puts it:

In creative writing we owe it to our students to examine how texts actually exist and are used in the world beyond the workshop. The workshop needs to address lived situations rather than assuming and perpetuating the presence of a falsely sublime (generally a white, educated, middle-class) reader. (Green 2001: 162)

How texts are used, what happens to them when they go out into the world, what work they are trying to do are important questions to consider in the workshop. The controversy surrounding American Psycho shows how fraught a text's reception can be, and that how a text is read and used can reverberate far beyond the writer's intentions. I'm sure that Bret Easton Ellis had no desire to incite readers to act violently against women, but some readers certainly read or misread the author's intentions in this manner. A writer cannot always know, control or predict how his work will be received.

Teaching the writing of violence brings questions about the use of the text into focus more clearly and more obviously than teaching students how to write a love poem or a pastoral poem. But time permitting, a discussion of the history and cultural functions of love poetry is well worth attempting. This consideration of what use a text can be put to is easier to discern when the function of the text is social protest. Both Green and Dawson cite examples from the poetry of protest. But a text might be used for other purposes than social protest, it might simply be intended to entertain and amuse, stimulate and seduce, or provoke visceral horror and fear. When students write violence sometimes all they are trying to do is entertain and amuse, chill and shock. Consider this extract from a story written by a second year student, where the killer is a young woman:

The father hits the brake and pulls over to the side of the road, but as he turns around to confront you, you're smart enough to have already made your move. Your hand instinctively darts into your shoe, grabs your shiny, newest knife and pierces straight through his thorax.

His eyes start to roll back into his head and you laugh victoriously as the blood gushes out of his throat and down your relaxed fingertips. You worry about the bloodstains on your hands, plus your new knife is not so shiny anymore. The bitch and the baby are screaming hysterically with that beautiful sound of helpless fear as the joy overwhelms you. (Matthews 2007: 7)

There are two killers in this story, a serial killing male truck-driver and the fifteen-year-old woman represented above, and they eventually meet in the story's climax. In a workshop discussion this text could be placed beside other examples written from the point of view of a violent protagonist. Comparing it with either McCabe or Dostoevsky might suggest that the protagonist is not psychologically convincing. Ellis' work might suggest that the violence does not appear to have any allegorical function, that there is no analysis of the causes of violence within society, and that this representation of violence seems to have no symbolic or metaphorical rationale. Such a discussion might conclude that the crucial problem with the writing is not with characterisation or descriptive detail, not with issues of craft, but simply with the ambition of the writer: that what the writer is trying to do is aesthetically and culturally limited. 
The discussion might also consider the question of authorial responsibility, the extent to which the author is perpetuating violent stereotypes or trying to interrogate and understand the place of violence within a culture. Can the author's representations of violence be justified? If so, how? Is this writing potentially offensive to readers and, if so, what should the author's response be? What process should an author use to make a decision about these issues? The workshop discussion would attempt to consider as many of these issues as practicable and to canvass a range of answers. After such a discussion, the student might still decide to write violent schlock as well as he can, and that is his choice. But it is the role of a university creative writing class to expand what can be achieved and to challenge students to be daring in what, how and why they write.

I want to briefly consider some practical implications of this approach. One implication is that some of the teaching-learning time needs to be allocated to the consideration of exemplary texts that aren't written by students. A lecture series can easily do this; a course reader or a set text can also fulfill this function. Sometimes discussion of a student's work might benefit from being deferred or returned to after the whole class has completed the suggested reading. Course readings can and should be chosen because they are likely to open up the discussion of a range of issues. Violence will do this. The issues associated with writing sex, as canvassed by Nigel Krauth 's 2007 paper, 'The pen in the ink-pot: teaching erotic writing' will also open up these lines of investigation. The literatures of resistance, social protest and witness are also useful. In my experience it's not practical and it's not desirable to subject every student text to this sort of scrutiny, but it's certainly worth doing when the opportunity arises. What students write and the ramifications of that writing for the world they live in is in danger of being neglected in a classroom that focuses exclusively on matters of craft.

Whether you call this approach sociological poetics as Dawson does, link it to cultural studies as Green does, or stress the role of the imagination and ethics as Surma does, is not important. What is important is that the relatively new practice of teaching creative writing at university is informed by a reflective and nuanced understanding of the potential of the writing workshop. What we want to do is to develop craft skills in our students at the same time as we help them to consider the political, ideological and social dimensions of their writing. The gun can go off in the workshop, but what that means for both writers and readers should be reflected upon, analyzed and discussed if we are really serious about teaching well and teaching effectively.

\section{List of works cited}

Coetzee, JM 1986 'Into the dark chamber: the writer and the South African state', in David Attwell (ed) 1992, Doubling the point: essays and interviews, Cambridge, Massachusetts: Harvard University Press, 361-68 return to text

Coetzee, JM 2000 Waiting for the barbarians, London: Random House (originally published 1980) return to text

Dawson, Paul 2003 'Towards a new poetics in creative writing pedagogy', TEXT 7.1, http://www.textjournal.com.au/april03/dawson.htm return to text

Donoghue, Denis 1998 The practice of reading, New Haven and London: Yale University Press return to text

Dostoevsky, Fyodor 1993 Crime and punishment (trans Richard Pevear and Larissa

Volokhonsky), London: Vintage return to text 
Ellis, Bret Easton 1991 American Psycho, London: Picador return to text

Foucault, Michel 1977 Discipline and punish: the birth of the prison (trans Alan Sheridan),

London: Penguin return to text

Freccero, Carla 1997 'Historical violence, censorship and the serial killer: the case of American Psycho', Diacritics 27.2, 44-58 return to text

Green, Chris 2001 'Materializing the sublime reader: cultural studies, reader response and community service in the creative writing workshop', College English 64.2 (November) 153-74 return to text

Grenville, Kate 2006a The secret river, Melbourne: Text Publishing (originally published 2005) return to text

Grenville, Kate 2006b Searching for the secret river, Melbourne: Text Publishing return to text Jarrett, Robert L 1997 Cormac McCarthy, New York: Twayne Publishers return to text

Krauth, Nigel 2007 'The pen in the ink-pot: teaching erotic writing', The ... and is ... papers: proceedings of the 12th conference of the AAWP, http://creative.canberra.edu.au/aawp/papers/KRAUTH.pdf (accessed 18 August 2008) return to text

La Guma, Alex 1972 In the fog of the season's end, London: Heinemann return to text

Love, Robert 1991 'Psycho analysis', Rolling Stone 459 (July), 39-40 return to text

Mailer, Norman 1991 'The children of the Pied Piper', Vanity Fair 54.3, 124-29 (182-83 UK edition) return to text

Mandel, Naomi 2006 '"Right here in nowheres": American Psycho and violence's critique', in Alain-Philippe Durand and Naomi Mandel (eds), Novels of the contemporary extreme, London and New York: Continuum, 9-19 return to text

Matthews, David 2007 'Hazel eyes', unpublished student manuscript (used with permission) return to text

McCabe, Patrick 1992 The butcher boy, London: Pan return to text

McCarthy, Cormac 1990 Blood meridian or The evening redness in the west, London: Picador (originally published 1985) return to text

Moore, Lorrie 1990 'Trashing women, trashing books', The New York Times, 5 December http://www.nytimes.com/books/98/09/20/specials/moore-trashing.html?_r=1 (accessed 20 March 2008) return to text

Murphet, Julian 2002 Bret Easton Ellis's American Psycho, New York and London: Continuum return to text

Peckinpah, Sam, Roy N Sickner, and Walon Green 1969 The Wild Bunch, Burbank: Warner Brothers-Seven Arts return to text

Phillips, Dana 1996 'History and the ugly facts of Cormac McCarthy's Blood Meridian', American literature, 68.2, 433-60 return to text

Sepamla, Sipho 1981 A ride on the whirlwind: a novel of Soweto, Johannesburg: Ad Donker return to text

Serote, Mongane 1981 To every birth its blood, Johannesburg: Ravan return to text

Surma, Anne 2000 'Defining professional writing as an area of scholarly activity', TEXT 4.2

(October) return to text 
Tompkins, Jane P 1985 Sensational design: the cultural work of American fiction, 1790-1860, New York: Oxford University Press return to text

Weil, Simone 1986 'The Iliad or the poem of force', Simone Weil, an Anthology, London: Virago, 182-201 return to text

Young, Elizabeth 1992 'The beast in the jungle; the figure in the carpet' in Elizabeth Young and Graham Caveney (eds), Shopping in space: essays on American blank generation fiction, London and New York: Serpent's Tail, 85-122 return to text

Andy Kissane has recently published fiction in The Sleepers Almanac series. His third book of poetry, Bread, will be published by Puncher \& Wattmann in 2009. He is currently a lecturer in creative writing in the School of English, Media and Performing Arts at the University of New South Wales.

\section{TEXT}

Vol 12 No 2 October 2008

http://www.textjournal.com.au

Editors: Nigel Krauth \& Jen Webb

Text@griffith.edu.au 